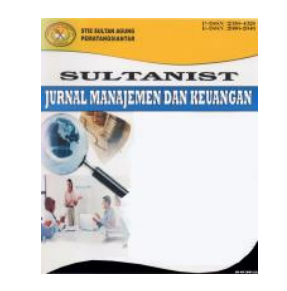

SULTANIST: Jurnal Manajemen dan Keuangan

Volume: 7 No: 2 Tahun 2019 Page (1-10)

ISSN: 2338-4328 (Print), ISSN: 2686-2646 (Online)

Available online at: https://sultanist.ac.id/index.php/sultanist

\title{
DETERMINAN KEBIJAKAN DIVIDEN PADA SEKTOR NONKEUANGAN
}

\author{
Ahmad Aziz Putra Pratama \\ Magister Sains Manajemen, Departemen Manajemen \\ Fakultas Ekonomi dan Bisnis Universitas Airlangga \\ Ahmad.aziz.putra-2018@feb.unair.ac.id
}

\begin{abstract}
Abstrak
Dividen yang diperoleh merupakan salah satu alasan investor untuk menanamkan dananya pada suatu perusahaan. Dividen merupakan kebijakan yang penting dalam perusahaan karena menyangkut pemegang saham yang notabene merupakan sumber modal dari perusahaan tersebut. Investor dalam menginvestasikan dananya kedalam instrumen saham tentunya menginginkan return yang tinggi. Penelitian ini bertujuan untuk mengetahui pengaruh size, leverage, growth opportunities, return on on equity, price earning ratio, quick ratio, dan free cash flow terhadap kebijakan dividen pada perusahaan nonkeuangan yang terdaftar di Bursa Efek Indonesia selama periode 2013-2018. Data diperoleh berdasarkan informasi pada laporan keuangan dan tahunan perusahaan. Penelitian ini menggunakan sampel 122 perusahaan dengan jumlah pengamatan sebanyak 732 pengamatan dengan menggunakan metode purposive sampling dan model regresi linier berganda. Penelitian diolah menggunakan SPSS 25 Statistic for Windows. Variabel independen pada penelitian ini adalah size, leverage, growth opportunities, return on on equity, price earning ratio, quick ratio, dan free cash flow. Variabel dependen dalam penelitian ini adalah kebijakan dividen. Berdasarkan hasil analisis dapat disimpulkan bahwa size dan price earning ratio berpengaruh positif signifikan terhadap kebijakan dividen. Quick ratio dan free cash flow berpengaruh positif tidak signifikan terhadap kebijakan dividen. Leverage dan return on on equity berpengaruh negatif tidak signifikan terhadap kebijakan dividen dan growth opportunities berpengaruh negatif signifikan terhadap kebijakan dividen.
\end{abstract}

Kata Kunci : Kebijakan dividen, Sektor nonkeuangan, regresi linear berganda

\section{DETERMINANT OF DIVIDEND POLICY IN THE NON-FINANCIAL SECTOR}

\section{Abstract}

Obtained dividends are one of the reasons for investors to invest their funds in a company. Dividends are an important policy in a company because it involves shareholders who incidentally are a source of capital from the company. Investors in investing funds into stock instruments certainly want a high return. This study aims to determine the effect of size, leverage, growth opportunities, return on equity, price earning ratio, quick ratio, and free cash flow on dividend policy on non-financial companies listed on the Indonesia Stock Exchange during the 2013-2018 period. Data obtained based on information on the firm's financial and annual reports. This study used a sample of 122 companies with a total of 732 observations using the purposive sampling method and multiple linear regression models. This research was processed using SPSS 25 Statistics for Windows. The independent variables in this study are size, leverage, growth opportunities, return on equity, price earnings ratio, quick ratio, and free cash flow. The dependent variable in this study is dividend policy. Based on the results of the analysis, it can be concluded that the size and price earning ratio have a significant positive effect on dividend policy. Quick ratio and free cash flow have a significant positive effect on dividend policy. Leverage and return on equity do not have a significant negative effect on dividend policy and growth opportunities have a significant negative effect on dividend policy.

Keywords: Dividend policy, non-financial sector, multiple linear regression 


\section{PENDAHULUAN}

Kebijakan dividen (dividend policy) merupakan keputusan apakah laba yang diperoleh perusahaan pada akhir tahun akan dibagi kepada pemegang saham dalam bentuk dividen atau akan ditahan untuk menambah modal guna pembiayaan investasi di masa yang akan datang (Martono dan Harjito 2000:253). Keputusan dividen merupakan bagian dari keputusan pembelanjaan perusahaan, khususnya berkaitan dengan pembelanjaan internal perusahaan. Hal ini karena besar kecilnya dividen yang dibagikan akan memengaruhi besar kecilnya laba yang ditahan. Laba ditahan merupakan salah satu sumber dana internal perusahaan (Sudana 2015:192).

Pentingnya keputusan mengenai kebijakan dividen ini muncul dari keterkaitannya dengan kebijakan perusahaan lainnya, seperti investasi dan pembiayaan, dan dampaknya terhadap kekayaan pemegang saham dan keseluruhan ekonomi. Kebijakan dividen yang optimal pada suatu perusahaan adalah kebijakan keseimbangan diantara dividen saat ini dan pertumbuhan di masa mendatang sehingga memaksimumkan harga saham (Astuti, 2004:144).

Menurut Sjahrial (2002), perusahaan akan tumbuh dan berkembang, kemudian pada waktunya akan memperoleh keuntungan atau laba. Laba ini terdiri dari laba yang ditahan dan laba yang dibagikan. Pada tahap selanjutnya laba yang ditahan merupakan salah satu sumber dana yang paling penting untuk pembiayaan pertumbuhan perusahaan. Makin besar pembiayaan perusahaan yang berasal dari: laba yang ditahan di tambah penyusutan aktiva tetap, maka makin kuat posisi finansial perusahaan tersebut. Dari seluruh laba yang diperoleh perusahaan sebagian dibagikan kepada pemegang saham berupa dividen. Mengenai penentuan besarnya dividen yang akan dibandingkan itulah yang merupakan kebijakan dividen dari pimpinan perusahaan. Rasio pembayaran dividen adalah persentase laba yang dibayarkan dalam bentuk dividen, atau rasio antara laba yang dibayarkan dalam bentuk dividen dengan total laba yang tersedia bagi pemegang saham (Sartono, 2001:491). Menurut Ferry dan Jones (dalam Sujianto, 2001), ukuran perusahaan menggambarkan besar kecilnya suatu perusahaan yang ditunjukkan oleh total aktiva, jumlah penjualan, rata-rata total penjualan dan rata-rata total aktiva. Jadi, ukuran perusahaan merupakan ukuran atau besarnya asset yang dimiliki oleh perusahaan.

Leverage timbul karena perusahaan untuk menggunakan aktiva atau dana yang mempunyai beban tetap (fixed cost assets or funds) yang gunanya untuk memperbesar tingkat penghasilan (return) bagi pemilik perusahaan (Syamsuddin, 2002:90). Selanjutnya, menurut Martono dan Harjito (2008:295), Rasio leverage mengacu pada penggunaan asset dan sumber dana oleh perusahaan dimana dalam penggunaan asset atau dana tersebut perusahaan harus mengeluarkan biaya tetap atau beban tetap. Semakin tinggi leverage perusahaan maka semakin tinggi laba yang ditahan, karena laba yang dimiliki oleh perusahaan akan digunakan untuk membayar kewajiban berupa beban tetap terlebih dahulu.

Growth merupakan aktiva atau aset yang digunakan dalam aktiva operasional perusahaan untuk meningkatkan pertumbuhan perusahaan (Marietta dan Sampurno, 2013). Perusahaan yang pertumbuhannya tinggi mempunyai kesempatan yang memungkinkan untuk membayar dividen yang lebih rendah karena mereka mempunyai kesempatan yang menguntungkan dalam mendanai investasinya secara internal, sehingga tidak terdorong untuk membayar bagian laba yang lebih besar kepada investor. Sebaliknya perusahaan yang pertumbuhannya rendah berusaha menarik dana dari luar untuk mendanai investasinya dengan mengorbankan sebagian besar labanya dalam bentuk dividen (Kodrat dan Herdinata, 2009:136). Pernyataan tersebut didukung oleh Smith dan Watts (1992) dan Sulistyowati (2003) yang mengemukakan bahwa perusahaan yang memiliki peluang investasi akan lebih memilih pendanaan 
internal daripada eksternal, akibatnya kebijakan dividen lebih menekankan pada pembayaran dividen yang kecil.

Kemampuan perusahaan menghasilkan laba salah satunya dapat diukur menggunakan rasio pengembalian modal atau return on equity. Return on equity menggambarkan kemampuan perusahaan dalam menghasilkan laba dengan menggunakan modal sendiri, sehingga Return on Equity yang sering disebut juga Return on Net Worth menggambarkan sejauh mana kemampuan perusahaan dalam menghasilkan keuntungan atau laba yang bisa diperoleh pemegang saham (Tandelilin, 2007). Rasio ini terkait dengan keuntungan perusahaan terhadap sumber pembiayaan modal.

Return on equity merupakan rasio yang memberikan informasi pada para investor tentang seberapa besar tingkat pengembalian modal dari perusahaan yang berasal dari kinerja perusahaan menghasilkan laba. Semakin besar nilai return on equity maka tingkat pengembalian yang diharapkan investor juga besar. Semakin besar nilai return on equity maka perusahaan dianggap semakin menguntungkan, oleh sebab itu investor kemungkinan akan mencari saham ini sehingga menyebabkan permintaan bertambah dan harga penawaran di pasar sekunder terdorong naik (Chastina Yolana dan Dwi Martani, 2005 dalam Tita Deitiana, 2013).

Menurut Hery (2015:169), price earning ratio merupakan rasio yang menunjukkan hasil perbandingan antara harga pasar per lembar saham dengan laba per lembar saham. Abdullah dan Agaki (2014) mengemukakan bahwa price earning ratio (PER) mengandung informasi mengenai laba bersih (earning per share) yang diperoleh perusahaan. Sebagaimana disebutkan dalam teori bahwa PER menunjukkan kemampuan perusahaan dalam menghasilkan laba bersih. Secara teoritis laba bersih digunakan untuk memprediksi nilai dividen yang akan dibayarkan oleh perusahaan. Peningkatan jumlah dividen yang dibayarkan menandakan bahwa laba bersih perusahaan juga mengalami peningkatan. Sebagaimana prinsip Signalling, adanya kenaikan dividen merupakan sinyal bagi investor dipasar modal bahwa perusahaan memiliki prospek yang bagus di masa mendatang.

Berdasarkan latar belakang diatas, penelitian ini mencoba untuk mengidentifikasi faktor - faktor yang mempengaruhi kebijakan dividen yaitu; ukuran perusahaan, leverage, growth opportunities, return on equity, price earning ratio, quick ratio, free cash flow. Penelitian ini menggunakan sampel perusahaan nonkeuangan yang terdaftar di Bursa Efek Indonesia (BEI).

\section{LANDASAN TEORI}

\section{Kebijakan Dividen}

Menurut Aharony dan Swary (1980) dalam Nurhidayati (2006) mengemukakan bahwa informasi yang diberikan pada saat pengumuman dividen lebih berarti daripada pengumuman earning. Bagi para investor, dividen merupakan hasil yang diperoleh dari saham yang dimiliki, selain capital gain. Dividen tersebut didapat dari perusahaan sebagai distribusi yang dihasilkan dari operasi perusahaan. Sedangkan Ambarwati (2010:64), mengemukakan bahwa kebijakan dividen adalah kebijakan yang diambil manajemen perusahaan untuk memutuskan membayarkan sebagian keuntungan perusahaan kepada pemegang saham dari pada menahannya sebagai laba ditahan untuk diinvestasikan kembali agar mendapatkan capital gains. Pada penelitian sebelumnya, kebijakan dividen diukur menggunakan Dividend Payout Ratio (DPR), yang merupakan rasio pendapatan yang dibayarkan kepada pemegang saham dalam bentuk dividen dengan jumlah total pendapatan perusahaan.

\section{Teori Kebijakan Dividen}

Sudana (2011:167) menyatakan bahwa terdapat tiga teori tentang kebijakan dividen. Ketiga teori tersebut yaitu: 


\section{SULTANIST: Jurnal Manajemen dan Keuangan, Vol 7 (2), 2019}

\section{Teori Dividend Irrelevance}

Teori yang dikemukakan oleh Modigliani dan Miller ini menerangkan bahwa, kebijakan dividen tidak memengaruhi harga pasar saham perusahaan atau nilai perusahaan. Mereka berpendapat bahwa nilai perusahaan hanya ditentukan oleh kemampuan perusahaan untuk menghasilkan pendapatan (earning power) dan risiko bisnis, sedangkan bagaimana membagi arus pendapatan menjadi dividen dan laba ditahan tidak memengaruhi nilai perusahaan. Penurunan harga pasar saham karena pembelanjaan eksternal berbanding lurus dengan kenaikan harga saham karena pembayaran dividen.

\section{Teori Bird-In-the-Hand}

Teori yang dikemukakan oleh Gordon dan Lintner ini menjelaskan bahwa, kebijakan dividen berpengaruh positif terhadap harga pasar saham. Artinya, jika dividen yang dibagikan perusahaan semakin besar, maka harga pasar saham perusahaan tersebut akan semakin tinggi dan sebaliknya.

\section{Teori Tax Preference}

Berdasarkan teori tax preference, kebijakan dividen mempunyai pengaruh negatif terhadap harga pasar saham perusahaan. Sehingga, semakin besar jumlah dividen yang dibagikan oleh suatu perusahaan, semakin rendah harga pasar saham perusahaan yang bersangkutan. Hal ini terjadi jika ada perbedaan antara tarif pajak personal atas pendapatan dividen dan capital gain.

Selain teori diatas terdapat dua teori lain yang dapat membantu untuk memahami kebijakan dividen adalah (Brigham, 2004 seperti dikutip Setiawati, 2012): Teori Information Content atau Signalling Hypothesis. Di dalam teori ini Modigliani dan Miller berpendapat bahwa suatu kenaikan dividen yang diatas kenaikan normal biasanya merupakan suatu sinyal kepada para investor bahwa manajemen perusahaan meramalkan suatu penghasilan yang baik dimasa yang akan datang. Sebaliknya, suatu penurunan atau kenaikan dividen yang dibawah kenaikan normal diyakini investor sebagai suatu sinyal bahwa perusahaan menghadapi masa sulit dimasa mendatang. Namun demikian sulit dikatakan apakah kenaikan atau penurunan harga setelah adanya kenaikan atau penurunan dividen semata-mata disebabkan oleh efek sinyal atau mungkin disebabkan oleh efek sinyal dan preferensi terhadap dividen.

Teori Clientele Effect

Teori ini menyatakan bahwa pemegang saham yang berbeda akan memiliki preferensi yang berbeda terhadap kebijakan dividen perusahaan. Kelompok investor yang membutuhkan penghasilan saat ini lebih menyukai dividend payout ratio (DPR) yang tinggi, sebaliknya kelompok investor yang tidak begitu membutuhkan uang saat ini lebih senang jika perusahaan menahan sebagian besar laba bersih perusahaan.

\section{Teori keagenan (Agency Theory)}

Manajer dan pemegang saham merupakan orang yang berbeda. Manajer dipandang sebagai agen dari pemilik atau pemegang saham (Widayanti, 2009). Seringkali antara manajemen dan pemegang saham memiliki kepentingan yang berbedabeda dan bertentangan, sehingga dapat terjadi konflik di dalamnya. Kebijakan deviden terkait dengan hubungan antara manajer dengan pemegang saham yang memiliki kepentingan yang berbeda diantaranya manajer menghendaki pembagian dividen kecil karena perusahaan membutuhkan dana yang besar untuk membayar utang perusahaan yang tinggi, atau perusahaan membutuhkan dana yang besar juga untuk mendanai kegiatan investasinya, sementara para pemegang saham menghendaki pembagian dividen yang besar. Perbedaan antara kepentingan pemilik atau pemegang saham dan kepentingan manajer tersebut menimbulkan apa yang disebut dengan masalah keagenan (agency problem) (Widayanti, 2009).

\section{Penelitian Terdahulu}

Penelitian Kouki (2009) menguji hubungan antara dividend payout ratio dengan free cash flow, ownership structure, manager share holding, size, leverage dan 
profitability. Hasil penelitian tersebut mengindikasikan bahwa terhadap hubungan positif antara profitability, size,ownership structure, dan free cash flow pada kebijakan pembayaran dividen, serta terdapa hubungan negatif antara variabel leverage, manager ownership dengan kebijakan pembayaran dividen. Sampel yang digunakan dalam penelitian Kouki (2009) ini adalah perusahaan yang terdaftar pada Toronto Stock Exchange pada periode 2002-2003 dengan sampel 400 perusahaan. Rizki Islamiyah (2012) melakukan penelitian dengan judul "Pengaruh Free Cash Flow, Profitabilitas, Likuiditas, Leverage dan Growth terhadap Kebijakan Dividen pada Perusahaan Manufaktur di BEI. Terhadap DPR". Sampel yang digunakan adalah laporan keuangan tahunan pada perusahaan manufaktur oleh auditor independen dan terdaftar pada Bursa Efek Indonesia untuk tahun 2006 sampai dengan tahun 2010. Variabel dependen yang digunakan adalah dividen payout ratio, sedangkan variabel independen yang digunakan adalah free cash flow, profitabilitas, likuiditas (CR), leverage (DER), dan growth. Teknik analisa yang digunakan adalah regresi linear berganda. Hasil dari penelitian tersebut adalah secara parsial variabel profitabilitas, leverage, dan growth berpengaruh negatif terhadap DPR. Secara parsial variabel free cash flow dan likuiditas berpengaruh positif terhadap variabel DPR. Semua variabel dalam penelitian ini tidak berpengaruh signifikan terhadap DPR.

Berdasarkan perumusan masalah dan landasan teori yang diajukan, maka hipotesis dalam penelitian ini adalah:

1. Ukuran perusahaan berpengaruh positif terhadap dividend payout ratio pada perusahaan nonkeuangan yang terdaftar di Bursa Efek Indonesia tahun 20132018.

2. Leverage berpengaruh negatif terhadap dividend payout ratio pada perusahaan nonkeuangan yang terdaftar di Bursa Efek Indonesia tahun 2013-2018.

3. Growth opportunities berpengaruh negatif terhadap dividend payout ratio pada perusahaan nonkeuangan yang terdaftar di Bursa Efek Indonesia tahun 2013-2018.

4. Return on equity berpengaruh positif terhadap dividend payout ratio pada perusahaan nonkeuangan yang terdaftar di Bursa Efek Indonesia tahun 20132018.

5. Price earning ratio berpengaruh positif terhadap dividend payout ratio pada perusahaan nonkeuangan yang terdaftar di Bursa Efek Indonesia tahun 20132018.

6. Quick ratio berpengaruh positif terhadap dividend payout ratio pada perusahaan nonkeuangan yang terdaftar di Bursa Efek Indonesia tahun 2013-2018.

7. Free cash flow berpengaruh negatif terhadap dividend payout ratio pada perusahaan nonkeuangan yang terdaftar di Bursa Efek Indonesia tahun 20132018.

Pendekatan penelitian yang digunakan adalah pendekatan kuantitatif yang menitikberatkan pada pengujian hipotesis, data yang digunakan harus terukur, dan akan menghasilkan kesimpulan yang dapat digeneralisasikan. Jenis data yang digunakan dalam penelitian ini adalah data eksternal sekunder yang disusun berupa data panel laporan keuangan perusahaanperusahaan non-financial yang terdaftar di Bursa Efek Indonesia pada periode 20132018. Data panel merupakan gabungan antara cross-section (silang) dan data time series (deret/runtut waktu). Data crosssection terdiri atas beberapa objek (Yamin, Rachmah, dan Kurniawan, 2011:199). Data deret waktu (time series) adalah data yang dikumpulkan dari waktu ke waktu (hari ke hari, minggu ke minggu, bulan ke bulan, atau dari tahun ke tahun) (Supranto, 2008:37). Teknik analisis yang digunakan dalam penelitian ini adalah analisis regresi linier berganda (Multiple Regression Analysis).

$$
\begin{aligned}
\mathrm{DPR}_{\mathrm{i}, \mathrm{t}}= & \alpha_{i}+\beta_{1} \text { Size }_{i, t-1}+\beta_{2} \text { Leverage }_{i, t-1} \\
& +\beta_{3} \text { Growth }_{i, t-1}+\beta_{4} \text { ROE }_{i, t}+ \\
& \beta_{5} \text { PER }_{i, t-1}+\beta_{6} \text { Quick ratio }_{i, t-1+}+ \\
& \beta_{7} F C F_{i, t-1}+\mu_{i t}
\end{aligned}
$$




\section{PEMBAHASAN}

Perusahaan yang digunakan sebagai sampel dari penelitian ini adalah seluruh perusahaan nonkeuangan yang terdaftar di Bursa Efek Indonesia (BEI) dari tahun 2013 sampai dengan tahun 2018. Perusahaan nonkeuangan merupakan perusahaan bukan bank atau lembaga keuangan lainnya. Berdasarkan data pada Bursa Efek Indonesia (BEI), sampel yang digunakan pada penelitian ini berjumlah 122 perusahaan dengan 732 observasi. Tabel 4.1 menunjukkan deskriptif variabel yang meliputi minimum (nilai minimal), maximum (nilai maksimal), mean (rata-rata) dan standard deviation (standar deviasi) dari masing-masing variabel penelitian. Tabel 4.2 menunjukkan hasil analisis regresi linear berganda.

Tabel 4.1 Deskripsi Statistik

\begin{tabular}{lrrrrr}
\hline & N & Min & Max & Mean & $\begin{array}{r}\text { Standard } \\
\text { Deviation }\end{array}$ \\
\hline DPR & 732 & 0,01 & 0,78 & 0,27 & 0,17 \\
SIZE & 732 & 25,58 & 33,13 & 28,91 & 1,47 \\
LEVERAGE & 732 & 0,07 & 0,90 & 0,45 & 0,18 \\
GROWTH & 732 & $-0,10$ & 3,61 & 0,20 & 0,30 \\
ROE & 732 & 0,01 & 0,44 & 0,15 & 0,08 \\
PER & 732 & $-7,17$ & 75,00 & 17,34 & 11,81 \\
QUICK RATIO & 732 & 0,16 & 10,71 & 1,56 & 1,34 \\
& & & & & 0,12 \\
FCF & 732 & $-0,73$ & 0,55 & 0,01 & \\
\hline
\end{tabular}

Sumber: Hasil olah data penulis periode 2013-2018

Pada tabel 4.1 diketahui bahwa nilai minimum DPR adalah sebesar 0,01 atau sebesar $1 \%$ dan nilai maksimum DPR sebesar 0,78 atau sebesar $78 \%$, dengan nilai rata-rata DPR sebesar 0,27 atau sebesar $27 \%$. Hal tersebut menunjukkan bahwa rata-rata perusahaan sampel pada tahun 2013 hingga 2018 cenderung membagikan dividen kepada pemegang saham dalam jumlah yang lebih sedikit dibandingkan dengan laba yang ditahan oleh perusahaan.
Tabel 4.2 Hasil Analisis Regresi

\begin{tabular}{lrrr} 
Variabel & $\begin{array}{r}\text { Koefisien } \\
\text { Regresi }\end{array}$ & t-statistik & Sig t \\
\hline Konstanta & $-0,256$ & $-1,537$ & 0,125 \\
Size & 0,020 & 3,122 & 0,020 \\
Leverage & $-0,096$ & $-1,375$ & 0,170 \\
Growth & $-0,078$ & $-2,141$ & 0,033 \\
ROE & $-0,202$ & $-1,518$ & 0,130 \\
PER & 0,003 & 3,640 & 0,000 \\
Quick ratio & 0,003 & 430 & 0,667 \\
FCF & 0,410 & 380 & 0,704 \\
& & & \\
R & & & 0,315 \\
R-square & & & 0,099 \\
F & & & 5,881 \\
Sig. F & & & 0,000 \\
\hline S. & & &
\end{tabular}

Sumber: Hasil olah data penulis periode 2013-2018

$D P R=$ Cash dividend /net income

Size $=$ log total assets

Leverage $=$ Total debt/total assets

Growth $=\left(\right.$ Total $_{\text {assets }}-$ - total $_{\text {assets }}$ t- $\left._{1}\right) /$ total assets $_{t-1}$

$R O E=$ Net income/total equity

$P E R=$ Stock pricelearning per share

Quick Ratio $=($ Current assets-inventory $) /$ current liabilities

$F C F=($ Net income + interest expenses + depreciation - CAPEX)/total assets

CAPEX $=$ Fixed assets $_{t}-$ Fixed asset $_{t-1}+$ Depreciation $_{t}$

\section{Pengaruh Size terhadap Kebijakan Dividen}

Hasil penelitian menunjukkan bahwa variabel size pada perusahaan nonkeuangan yang terdaftar di BEI tahun 2013-2018 berpengaruh positif signifikan terhadap dividend payout ratio. Hasil tersebut sesuai dengan hipotesis yang telah ditentukan sebelumnya. Hal ini didukung oleh penelitian Jensen dan Meckling (1976) yang menyatakan bahwa, "the payment of high dividends is an effective tool used by large firms, with dispersed ownership and powerful management, to send costly and 
significant cash signals to reveal management good faith and decent treatment of shareholders". Disebabkan karena ukuran perusahaan merupakan simbol yang berhubungan dengan peluang dan kemampuan perusahaan untuk masuk ke pasar modal dan jenis pembiayaan lainnya yang menunjukkan kemampuan untuk memperoleh dana yang lebih besar.

\section{Pengaruh Leverage terhadap Kebijakan Dividen}

Hasil penelitian menunjukkan bahwa variabel leverage pada perusahaan nonkeuangan yang terdaftar di BEI tahun 2013-2018 tidak berpengaruh terhadap dividend payout ratio. Peningkatan hutang akan mempengaruhi besar kecilnya laba bersih yang tersedia bagi para pemegang saham, termasuk dividen yang diterima karena kewajiban untuk membayar hutang lebih diutamakan daripada pembagian dividen, sehingga perusahaan tidak mempunyai dana yang lebih untuk membagikan dividen. Hasil tersebut sesuai dengan hipotesis yang telah ditentukan sebelumnya. Hasil hipotesis ini juga didukung oleh penelitian Chang dan Rhee (1990) yang menyatakan bahwa leverage mempunyai pengaruh negatif signifikan terhadap dividend payout ratio. Dwi (2012) menyatakan bahwa perusahaan dengan hutang yang tinggi cenderung akan membagikan dividen dalam jumlah yang lebih rendah. Alasan yang pertama yaitu, hutang dapat mempengaruhi kemampuan perusahaan untuk membayar dividen, hal ini disebabkan karena perusahaan membiayai kegiatan bisnisnya melalui hutang sehingga perusahaan memiliki kewajiban untuk membayar bunga dan pokok pinjaman. Kedua, pada beberapa perjanjian hutang berlaku pembatasan dalam pembagian dividen oleh pihak kreditur.

\section{Pengaruh Growth Opportunities terhadap Kebijakan Dividen}

Hasil penelitian menunjukkan bahwa variabel growth opportunities pada perusahaan nonkeuangan yang terdaftar di
BEI tahun 2013-2018 berpengaruh negatif signifikan terhadap dividend payout ratio. Hal ini disebabkan karena semakin cepat tingkat pertumbuhan suatu perusahaan, maka semakin besar pula kebutuhan dana yang diperlukan untuk membiayai pertumbuhan tersebut. Semakin besar kebutuhan dana untuk waktu mendatang maka perusahaan lebih senang untuk menanam labanya daripada membayarkan sebagian dividen kepada pemegang saham. Hasil penelitian ini juga sesuai dengan pernyataan Dempsey dan Laber (1992) yang menyatakan bahwa "cutting dividend is a means to sustain growth and reduce firms' reliance on costly external financing".

\section{Pengaruh Return on Equity terhadap Kebijakan Dividen}

Hasil penelitian menunjukkan bahwa bahwa variabel return on equity pada perusahaan nonkeuangan yang terdaftar di BEI tahun 2013-2018 berpengaruh negatif tidak signifikan terhadap dividend payout ratio. Hasil tersebut tidak sesuai dengan hipotesis yang telah ditentukan sebelumnya. Hal ini berarti bahwa perusahaan sampel lebih memilih untuk menjadikan laba ditahan sebagai sumber pendanaan perusahaan (yang sesuai dengan pecking order theory) daripada dibagikan sebagai dividen untuk pemegang saham.

\section{Pengaruh Price Earning Ratio terhadap Kebijakan Dividen}

Hasil penelitian menunjukkan bahwa variabel price earning ratio pada perusahaan nonkeuangan yang terdaftar di BEI tahun 2013-2018 berpengaruh positif signifikan terhadap dividend payout ratio. Hasil tersebut sesuai dengan hipotesis yang telah ditentukan sebelumnya. PER menunjukkan kemampuan perusahaan dalam menghasilkan laba bersih. Secara teoritis laba bersih digunakan untuk memprediksi nilai dividen yang akan dibayarkan oleh perusahaan. Peningkatan jumlah dividen yang dibayarkan menandakan bahwa laba bersih perusahaan juga mengalami peningkatan. Sebagaimana 
prinsip Signalling, adanya kenaikan dividen merupakan sinyal bagi investor dipasar modal bahwa perusahaan memiliki prospek yang bagus di masa mendatang.

\section{Pengaruh Quick Ratio terhadap Kebijakan Dividen}

Hasil penelitian menunjukkan bahwa variabel quick ratio pada perusahaan nonkeuangan yang terdaftar di BEI tahun 2013-2018 berpengaruh positif tidak signifikan terhadap dividend payout ratio. Hasil tersebut sesuai dengan hipotesis yang telah ditentukan sebelumnya. Perusahaan untuk membayar dividen memerlukan aliran kas keluar sehingga harus tersedia likuiditas yang cukup. Semakin tinggi likuiditas yang dimiliki perusahaan semakin mampu membayar dividen. Hal ini menunjukan bahwa perusahaan sampel lebih memilih untuk sedikit memberikan dividen kepada pemegang saham ketika perusahaan tidak memiliki cukup aset lancar.

\section{Pengaruh Free Cash Flow terhadap Kebijakan Dividen}

Hasil penelitian menunjukkan bahwa variabel free cash flow pada perusahaan nonkeuangan yang terdaftar di BEI tahun 2013-2018 berpengaruh positif tidak signifikan terhadap dividend payout ratio. Pengaruh tidak signifikan tersebut karena perusahaan memakai sumber-sumber lain untuk membayar dividen kepada pemegang saham. Hasil tersebut tidak sesuai dengan hipotesis yang telah ditentukan sebelumnya.

\section{KESIMPULAN DAN SARAN}

Berdasarkan hasil analisis yang telah dilakukan dalam penelitian ini dapat disimpulkan bahwa ukuran perusahaan berpengaruh positif signifikan terhadap dividend payout ratio pada perusahaan nonkeuangan yang terdaftar di Bursa Efek Indonesia tahun 2013-2018. Leverage berpengaruh negatif tidak signifikan terhadap dividend payout ratio pada perusahaan nonkeuangan yang terdaftar di Bursa Efek Indonesia tahun 2013-2018. Growth opportunities berpengaruh negatif signifikan terhadap dividend payout ratio pada perusahaan nonkeuangan yang terdaftar di Bursa Efek Indonesia tahun 2013-2018. Return on equity berpengaruh negatif tidak signifikan terhadap dividend payout ratio pada perusahaan nonkeuangan yang terdaftar di Bursa Efek Indonesia tahun 2013-2018. Price earning ratio berpengaruh positif signifikan terhadap dividend payout ratio pada perusahaan nonkeuangan yang terdaftar di Bursa Efek Indonesia tahun 2013-2018. Quick ratio berpengaruh positif tidak signifikan terhadap dividend payout ratio pada perusahaan nonkeuangan yang terdaftar di Bursa Efek Indonesia tahun 2013-2018. Free cash flow berpengaruh positif tidak signifikan terhadap dividend payout ratio pada perusahaan nonkeuangan yang terdaftar di Bursa Efek Indonesia tahun 2013-2018.

Sampel penelitian ini adalah perusahaan yang tergabung dalam perusahaan yang tercatat dalam Bursa Efek Indonesia periode 2013-2018. Sampel yang digunakan sejumlah 732 mungkin masih belum bisa mewakili hasil keseluruhan populasi. Hal ini mungkin akan berbeda jika dilakukan pada periode yang lebih panjang. Saran untuk penelitian selanjutnya dengan topik yang sama adalah perlu mempertimbangkan periode penelitian yang dapat ditambah sehingga dapat lebih mewakili keseluruhan populasi yang ada.

\section{DAFTAR PUSTAKA}

Adaoglu, Cahit. 2000. Instability in the Dividend Policy of the Istanbul Stock Exchange (ISE) Corporations: Evidence from an Emerging Market. Emerging Markets Review, (1): 252270.

Al-Kuwari, Duha. 2009. Determinants of the Dividend Policy in Emerging Stock Exchanges: The Case of GCC Countries. Global Economy and Finance Journal, Vol. 2, No. 2, pp. 38-63. 
Al-Malkawi, H. N. 2007. Determinants of Corporate Dividend Policy in Jordan. Journal of Economics and Administrative Sciences, vol. 23, No. 2, pp. 44-70.

Baker, H. Kent dan Gary E. Powell. 2012. Dividend Policy in Indonesia: Survey Evidence from Executives. Journal of Asia Business Studies, Vol. 6, Iss. 1, pp. 79-92.

Bhattacharya, S. 1979. Imperfect Information, Dividend Policy and the Bird in the Hand Fallacy Bell. Journal of Economics, 10: 259-270.

Brealey, Richard A, et al. 2007. Dasardasar Manajemen Keuangan Perusahaan. Edisi kedua. Terjemahan oleh Bob Sabran MM. 2008. Jakarta: Erlangga.

Brigham, Eugine F. \& F. H. Joel. 2010. Manajemen keuangan: Teori dan Penerapan. Buku 1. Edisi kedelapan. Terjemahan oleh Dodo Suhartono dan Herman Wibowo. Jakarta: Salemba Empat.

Damayanti, S dan Achyani, F. 2006. Analisis pengaruh Investasi, Likuiditas, Profitabilitas, pertumbuhan Perusahaan dan Ukuran Perusahaan terhadap kebijakan Dividend Payout Ratio. Jurnal Akuntansi dan Keuangan, Vol. 5, No. 1, p. 51-62.

Deitiana, Tita. 2009. Faktor-faktor yang Mempengaruhi Kebijakan Pembayaran Dividen Kas. Jurnal Bisnis dan Akuntansi, Vol. 11, No. 1, Hlm. 57-64.

Gill, Amarjit, et al. 2010. Determinants of Dividend Payout Ratio: Evidence from United State. The Open Business Journal, No. 3, pp. 8-14.

Gujarati, D. 1997. Ekonometrika dasar. Jakarta: Erlangga.
Hanafi, M. M. \& A. Halim. 2007. Analisis Laporan Keuangan. Edisi Kedua. Cetakan Pertama. Yogyakarta: UPP AMP YKPN.

Horne, James C Van \& John M. Wachowicz. 1997. Prinsip-prinsip Manajemen Keuangan. Jakarta: Salemba Empat.

Husnan, S. \& E. Pudjiastuti. 2008. Dasardasar Manajemen Keuangan Keuangan: Teori dan Penerapan. Buku 1. Edisi Kelima. Yogyakarta: BPFE.

Hussainey, Khaled, Chijoke Oscar Mgbame \& Aruoriwo M. Chijoke-Mgbame. 2011. Dividend Policy and Share Price Volatility: UK Evidence. The Journal of Risk Finance, Vol. 12, Iss 1, pp. 5768.

Irawati, S. 2006. Manajemen Keuangan. Cetakan kesatu. Bandung: Pustaka. Jabbouri, Imad. 2016. Determinants of Corporate Dividend Policy in Emerging Markets: Evidence from MENA Stock Markets. Research in International Business and Finance, (37): 283-298.

Jensen, Michael C. 1986. Agency Cost of Free Cash Flow, Corporate Finance and Takeovers. American Economics Review, Vol. 76, No. 2, pp. 323-329.

Junaidi. 2008. Pengaruh Perubahan Earning, Market Capitalization, dan Price to Book Value terhadap Dividend Policy. Jurnal Neo-Bis, Vol. 2, No. 2, Desember, p. 102-115.

Kaźmierska-Jóźwiak, Bogna. 2015. Determinants of Dividend Policy: Evidence from Polish Listed Companies. Procedia Economics and Finance. (23): 473-477. 
Kouki, Monder \& Moncef Guizani. 2009. Ownership Structure and Dividend Policy Evidence from the Tunisian Stock Market. European Journal of Scientific Research. Vol. 25. No. 1, pp. 42-53.

Marlina, L \& Danica, C. 2009. Analisis Pengaruh Cash Position, Debt to Equity Ratio, dan Return on Assets terhadap Dividend payout Ratio. Jurnal Manajemen Bisnis, 2 (1), p. 16.

Miller, M. H. \& Modigliani F. 1961. Dividend Policy, Growth and Valuation of Shares. Journal of Business, 34: 411-433.

Nindya, Anggu Putri. 2015. Pengaruh Debt to Equity, Profitabilitas, Growth, dan Ukuran Perusahaan terhadap Kebijakan Dividen. E-Proceeding of Mangement, Vol. 2, No. 1, Hlm. 488.

Prihantoro. 2003. Estimasi pengaruh Dividend Payout Ratio pada Perusahaan Publik di Indonesia. Jurnal Ekonomi dan Bisnis, 8 (1), p. 7-14.

Ross, et al. 2008. Pengantar Keuangan Perusahaan. Edisi kedelapan. Jakarta: Salemba Empat.

Riyanto, B. 2001. Dasar-dasar pembelanjaan Perusahaan. Yogyakarta: BPFE. Sartono, A. 2000. Manajemen Keuangan. Edisi Ketiga. Yogyakarta: BPFE. Sudana, I Made. 2011. Manajemen keuangan Perusahaan. Surabaya: Erlangga.

Sundjaja, R. S. \& Inge Barlian. 2003. Manajemen Keuangan 2. Edisi keempat. Jakarta: Literata Lintas Media.

Tsuji, Chikashi. 2010. What are the Determinant of Dividend Policy? The
Case of Japanese Electrical Appliance Industry. Business and Economics Journal, 2010: BEJ - 9

Utari, Dewi, et al. 2014. Manajemen Keuangan. Edisi Revisi. Jakarta: Mitra Wacana Media.

\section{Profil Singkat}

Ahmad Aziz Putra Pratama, Lahir di Rembang, tanggal 04 Mei 1996, lulus dari jurusan manajemen Universitas Airlangga pada tahun 2018 dan merupakan lulusan terbaik. Saat ini sedang menempuh pendidikan S-2 pada bidang magister sains manajemen Fakultas Ekonomi dan Bisnis Universitas Airlangga. Selain itu, penulis juga merupakan owner dan founder Monster Laut Indonesia dan Karya Pratama. 